\title{
Ground Water Basin Management
}

James H. Krieger** and Harvey O. Banks***

$\mathrm{D}$ ESPITE ITS recent drenching, Southern California is experiencing its eighteenth year of drought. The effects of low rainfall have been accentuated by increased per capita use of water and aggravated by a booming population resulting from the western migration. The result is a serious demand on California's water resouces, as well as on her scientific, engineering, nanagement, legal, and political resourcefulness in meeting the challenge.

The problein can be net in two ways: increase the supply or limit the demand. Both are necessary. Methods of increasing the supply range from experiments in saline water conversion, rain making and bizarre firtations with juvenile water, ${ }^{1}$ to bold and expensive projects to transport water great distances over the mountains from watersheds with surplus to areas of deficiency. Great aqueducts are not new in California, but the 1,750,000,000 dollar California Water Resources Development Bond Act to conserve and transport water from Northern California to Southern California is the most anibitious project of its kind in America. ${ }^{2}$

In limiting the deniand for water California has been less imaginative. Americans are less prone to curb their appetites than they are to invent new ways to satisfy them; hence, there lave been few attempts to stretch the available water supply. Conservation and reclamation are viewed as a last resort. While this philosophy is responsible in part for the people of California voting a nulti-billion dollar project to import water into thirsty areas, it is equally accountable for squandering the local supply.

One means of checking this waste lies in fully realizing the potential of the ground water resources of the state, followed by the inauguration and enforcenient of a basin nanagenient program of ample scope to maximize the use of the state's ground water basins.

ESSENTIALS OF BASIN MANAGEMENT

The basic objective of ground water basin managenent is to achieve the

* Member, California Bar.

** Consulting Civil Engineer; Fellow, American Society of Civil Engineers; former Director of Water Resources of California.

1 Juvenile water is "new water of magmatic, volcanic, or cosmic origin added to the terrestrial water supply." Tolaran, Ground Water 561 (1937).

2 California Water Resources Development Bond Act, CaI. WATER Code \$\$ 12930-44. 
maximum benefit in terms of water supply at minimum cost. Where other sources of supply in addition to the local ground waters are in use, attainment of this objective necessarily requires co-ordinated management of the several sources.

The hydrology of ground water is complex and dynamic. The amount of water that may be safely extracted from a ground water basin is not a fixed quantity, but may vary within rather wide limits as man's activities increase or decrease the supply to and disposal from the ground water body. These activities include, annong other things, artificial recharge, regulation of stream flow by surface storage, vegetal cover changes, extension of sewerage systems, paving of stream channels, and sealing of the ground surface by the spread of urbanization. Further, $m$ most cases, the safe yield of a basin under a particular set of surface conditions will depend upon limits within which water levels $\mathrm{m}$ the basin are allowed to fluctuate. To a considerable extent, the safe yield is increased by lowering the water level, since this conserves water that would otherwise waste from the basin through run-off, drainage, and evaporation.

Generally, operation of a ground water basin has been thought of in terms of conservation and utilization of local water resources for local use and for export to adjacent areas. These are by no means the only functions now served. In the future, increasing use will be made of water-bearing strata forming ground water basins to carry out the following functions.

1. Terminal storage, both regulatory and cyclic, of imported water. This is particularly important in Southern California, where large quantities of water must be imported from the north and where little surface storage capacity is available. Peaking requirements inust be inet to a considerable degree by pumping from the underground, simce the import aqueducts will not be large enough to meet maximum demands. Terminal cyclic storage is necessary to achieve better coordination with the other available sources of supply, some of which vary widely from year to year, depending on climatic conditions. Standby reserves may be necessary. It may be necessary to develop and use the underground storage capability of a given basin not only for the benefit of overlying water users, but also for the benefit of adjacent areas, which may not be so fortunately situated with respect to available underground storage capacity.

2. Treatment of imported water. Percolation through the sands and gravels in spreading basins or stream beds in the process of replenishing the ground water body will remove turbidity and bacterial contamination.

3. Distribution of imported water. Use of the water-bearing strata for distribution to the limit of their transmission capability will minimize the cost of surface distribution works.

4. Reclamation of sewage and industrial wastes of suitable quality. 
Storage for the reclaimed water is essential. Furthermore, passage through the soil provides a certain degree of treatment reducing organic content. Addition of the reclaimed water to the ground water body may provide some dilution and result in improved quality.

At some future time it may become necessary to fully develop the storage capabilities of the ground water basins in the Sacramento Valley. This may be required in order to achieve maximum conservation of the runoff of the streams tributary to the Valley for export to Central and Southern California. Available surface storage capacity is insufficient to effect the requisite degree of conservation. Ultimately it may be necessary to operate the ground water storage of the Sacramento Valley in conjunction with the large capacity available in certain portions of the San Joaquin Valley in order to provide sufficient long-term cyclic storage for conservation of northern runoff. Some of the water placed in storage in the San Joaquin Valley could be used for export to Southern California.

For purposes of further discussion, then, we may distinguish between the local ground water supplies that are available and have already been put to beneficial use, and the underground storage capacity that may be developed and put to further uses.

Effective basin management encompasses much more than hydrology, engineering, and legal rights, powers, and responsibilities. Also involved are complicated problems of economics, financing, and organization. Among the more complex and serious problems is the maintenance and protection of the quality of the waters concerned, not only against possible contamination and pollution resulting from the disposal of sewage and industrial wastes and from garbage and refuse dumps, but also against the intrusion of saline waters, degradation due to the return flows from irrigation, and deterioration due to lack of salt balance within the basin. The quality problem has only recently been recognized as one of major concern. ${ }^{3}$

Turning now to the legal problems involved in ground water basin management, we shall examine the following problem areas:

1. Determination of rights to the present ground water supplies and the early elimination of current overdrafts.

2. The right to develop and use underground storage capacity, with particular emphasis on the storage of imported water, and the joint use of stream beds and spreading works for artificial recharge.

3. The organizational structure and the powers and responsibilities of management agencies.

${ }^{3}$ See Water Quality Standards-A Symposium, 52 J. AMrERICAN WATER Works A. 1159 (1960). 
DETERMINATION OF RIGHTS AND ELIMINATION OF OVERDRAFT

The great drought commenced in 1944. Foreseeing the inadequacy of local supplies to meet the future needs of Southern California, the Metropolitan Water District of Southern California had been organized in 1928. In 1931 the voters within the Metropolitan District authorized a 220,000,000 dollar bond issue to construct an aqueduct to carry water from the Colorado River into the metropolitan area of Southern California. The project was completed in 1941. By 1949 a total of only 146,232 acre feet of Colorado River water had been delivered, even thought the aqueduct was then capable of transporting 550,000 acre feet annually. By 1961 only $5,540,089$ acre feet had been delivered, less than half the quantity that the aqueduct might have delivered had there been a demand for the water. Water users, lowever, persisted in pumping local supplies. Imported Colorado River water was not only more expensive, but there was a real danger that a pumper miglit lose his riglit to pump from the local supply if he discontinued pumping in favor of purchasing imported water. In 1951 the legislature sought to assure the pumper that he would not lose lis pumping right if he would merely report his purchases of imported water. ${ }^{5}$ Still pumpers did not respond. It was not until the late 1950's that imported water was purchased from Metropolitan in significant amounts. Only a few entities took advantage of the supplemental supply in the interim. The balance of the available supply was lost, even thougli ground water basin levels declined and the water supply situation in Soutliern California grew even more critical.

\section{A. The Raymond Basin Case}

The dilemma of communities dependent on ground water probably stems to some considerable extent from the 1949 decision of the California Supreme Court in City of Pasadena v. City of Alhambra. ${ }^{6}$ In 1937 the City of Pasadena sought an adjudication of water riglits withm a ground water basin known as the Raymond Basm Area. Pasadena, the principal producer in the basin, alleged that the basin had been subjected to a continual overdraft for a period of many years. Water levels were receding and the basin was threatened with destruction as a source of water unless pumping from

4 Formed under the Metropolitan Water District Act, CaI. Uncodnfied Water Laws act 9129 (Deermg 1962). See generally Metropolitan Water District v. Whitsett, $215 \mathrm{Cal}, 400$, 10 P.2d 751 (1932).

5 Car. Water Code $\S \S 1005.1-1005.2$.

633 Cal. 2d 908, 207 P.2d 17 (1949), cert. denied, 339 U.S. 937 (1950). See Hurchiss, The California Law of Water Rights 444-46, 504 (1956); Note, 37 Calif. L. Rev. 713 (1949). 
it was curtailed. The trial court referred the matter to the State Division of Water Resources as referee for the determination of the physical facts involved. ${ }^{7}$ An exhaustive study was made of the geological structure and hydrology of the basin, which substantially supported Pasadena's claim that the basin was in danger of depletion. ${ }^{8}$

The trial court found that because of the overdraft each pumper, in effect, had been pumping adversely against all other pumpers. It concluded that each party owned by prescription the right to withdraw an amount of water equal to the maximum continuously pumped over any five year period. ${ }^{9}$ In order to prevent further overdrafts, the rights of all the parties were reduced proportionately by about one-third, so that the total extracted would not exceed the safe yield of the basin. The Division of Water Resources was appointed "watermaster" to enforce the restrictions, and the court retained continuing jurisdiction to modify the judgment.

The Supreme Court of California affirmed. It recognized that under conditions of surplus rights would depend on ownership of overlying land and, between appropriators, priority in time. ${ }^{10}$ It agreed with the trial court, however, that when pumping exceeded the safe yield, so that a condition of overdraft existed in the basin, an enjoinable invasion of the rights of original owners had occurred. This adverse user was held to mature into a vested right if continued for the statutory period of five years. ${ }^{11}$ Apparently, unless a pumper could prove five years of continuous pumping in an overdrawn basin, he had no right at all.

Although there were no overlying owners in the case who were not also pumpers, the court stated that "if the original owners of water rights ... had failed to pump for a five-year period, ... the wrongdoers would have perfected prior prescriptive rights to the full amount which they pumped."12 This would seem to indicate that overlying owners who had never pumped at all could lose their ground water rights through prescription. Such a rule, applying against all future claimants, would permit complete judicial control of the basin.

In this respect, the Raymond Basin case affords the key to ground water basin management. By reducing the amount each party could extract, the decline of ground water levels in the basin was halted. The availability of water from the Metropolitan Water District made the physical solution workable. Increased return flows resulting from the use of larger amounts

733 Cal. 2d at 916, 917-18, 207 P.2d at 23-24; see CaL. Water Code $§ 2001$.

$833 \mathrm{Cal} .2 \mathrm{~d}$ at $928-29,207$ P.2d at 30.

${ }^{9} I d$. at $922,207 \mathrm{P} .2 \mathrm{~d}$ at 26 .

10 Id. at 926,207 P.2d at $28-29$.

11 Id. at 926-27, 207 P.2d at 29; see Cax. Civ. Code § 1007; Cax. Code Crv. Proc. § 321.

1233 Cal. $2 \mathrm{~d}$ at $931-32,207$ P.2d at 32. 
of imported water increase the safe yield of the basin. In 1955 the trial court, under its continuing jurisdiction, was able to increase the amount the parties might pump from the local supply. In short, full management of the Raymond Basin Area was effected by (1) determining the rights of each puniper in the basin; (2) determining the safe yield of the basin, and cutting back each pumper's right to enable the basin to be brought into balance; and (3) retaining jurisdiction and assigning the Department of Water Resources as waternraster to maintain contimuing surveillance of the basin. lation:

This solution suggests four basic principles of successful basin regu-

1. Complete knowledge of the geology and hydrology of a basin, including periodic determinations of its safe yield.

2. A legal determination of the quantity of water to which each pumper is entitled.

3. Continuing judicial control over the extractions of water by each person from the basin.

4. A source of supplemental water.

Should any one of these elenrents be lacking, there can be no absolute control over a basin.

When the Raymond Basin suit was commenced the parties had no idea that a new rule of law would be formulated to meet a unique situation. The principal pumpers in the basin were originally appropriators, to which the old rule of "first in time, first in right" was presumably applicable. ${ }^{13}$ Under this rule, the appropriators would have been cut back in inverse order until a condition of surplus was restored. But to have taken away the pumping rights of any of the parties would have resulted in taking the entire water supply away from some appropriators whose customers were completely dependent on that supply. Instead, the "mutuality of prescription" rule was developed. Each pumper was cut back, but each was allowed to survive. An elaborate "exchange agreement," worked out voluntarily by all the parties except one, and approved by the court, provided for water exchanges and financial arrangements ensuring an adequate water supply. ${ }^{14}$ The availability of imported Colorado River water was the last necessary piece in the involved puzzle.

\section{B. Reaction to the Raymond Basin Case}

Following the Raymond Basin case users of ground water throughout the state were put on notice that a new rule would govern their rights if they were pumping from an overdrawn basin. The right would be measured

13 City of San Bernardino v. City of Riverside, 186 Cal. 27, 198 Pac. 784, 793 (1921).

14 See Hutchons, op. cit. supra note 6, at 502 . 
by the quantity of water pumped. The race was on. Efforts to halt the race ${ }^{16}$ were stymied by the increasing demands on the municipal pumpers. By satisfying this demand, the municipal pumpers stood to increase their rights against irrigation pumpers and mutual water companies, whose demand was not increasing. The balance of influence lay with the entities that carried the obligation to serve the growing cities; hence, adjudications under the new rule were delayed even as the drought continued. Substantial taxes were paid by members of the Metropolitan Water District for the privilege of enjoying the right to purchase water that few users within the member political subdivisions actually wished to buy and use. Gradually these public agencies realized that there was more to existence than collecting taxes and paying them to Metropolitan for the right to receive water. Enabling acts were studied to determine how users could be urged or even compelled to purchase the water for which taxpayers were paying so dearly. The solutions evolved were many and varied.

In an attempt to stop the critical overdraft in Orange County, the legislature revised the Orange County Water District Act in 1953. The district was armed with extensive powers to purchase and spread supplemental water and at the same time impose a replenishment assessment, or pumping tax, on all persons operating water producing facilities. ${ }^{16}$ The pumping tax and an ad valorem real property tax operated in tandem to institute and maintain a program of purchasing supplemental water, which was either spread and later pumped from the underground, or turned directly into municipal mains by entities that found it economically advantageous to discontinue pumping from the underground. The result was a successful rehabilitation of a basin faced with eventual destruction due to sea water intrusion. From a county whose very existence was threatened by loss of its water supply, the area has become one of the fastest growing and most prosperous in California. ${ }^{17}$

In contrast to the approach used by the water interests in the Raymond Basin, the interests in Orange County have deliberately avoided an adjudication of their respective rights. Even though the basin was overdrawn and the mutuality of prescription rule might well have been apphed to the pumpers with matured prescriptive rights, the area took a non-litigious approach to the problem. Overlying rights and priorities were all set aside in favor of a physical solution. The community used its resources to purchase supplemental water, and immediately put it to work. ${ }^{18}$ When the

\footnotetext{
15 See note 5 supra.

16 Orange County Water District Act, Cat. UnconifIEd WaTER Laws act 5683, $\$ \S 2(6)$, 27 (Deering 1962).

${ }^{17}$ See Crooke and Toups, Ground Water Basin Management and Artificial Recharge in Orange County, California, a paper presented to the Biennial Conference on Ground Water Recharge, University of California at Berkeley, June 28, 1961.
} 
powers of the Orange County Water District were drastically changed in 1953, no power to initiate actions to adjudicate water rights within the district was included. ${ }^{19}$ No property owner or water user has seen fit to institute a basin adjudication on his own initiative. Even if such an action were commenced, there is nothing in the statute requiring the district to recognize prescriptive punping rights as there is in the Water Replenishment District Act of $1955 .^{20}$ Whether such an adjudicated right in the local supply would have to be recognized as a nuatter of law appears to be an academic question. The community is Inanaging its water affairs to the apparent satisfaction of water users, taxpayers, and public officials. However, Orange County is at the lower end of the Santa Ana stream system. It was the first to suffer and was the first to help itself. No other upstream user had any real reason to challenge what the downstreain user was doing. Affairs become nore complicated in the upstream reaches, where the problems become nore complex and interests overlap geological basin boundaries both upstream and downstream. While the Orange County Water District has been content to manage internal affairs within its basin without litigation, it has taken vigorous action to curtail upstream cities from taking more than their fair share of the stream supply. ${ }^{21}$ It is this inter-basin conflict that constitutes one of the chief problems in ground water basin management.

Another means of eliminating an overdraft by making use of an inported supply was devised by the West Basin Municipal Water District. ${ }^{22}$ It too is a nember of the Metropolitan Water District of Southern California and entitled to Colorado River water. It, like Orange County, is at the end of the stream system, suffering from a severe overdraft, and endangered by sea water imtrusion. In 1945 it instituted a basin-wide adjudication and requested a reference to the state Division of Water Resources ${ }^{23}$

$18 \mathrm{Ibid}$. The district took deliveries of $1,043,291.6$ acre feet of water from the Metropolitan Water District of Southern California from 1941 to 1960 , or a total of $23.1 \%$ of the total amount delivered by Metropolitan to its member agencies.

19 CAL. UNCODIFIED WaTER LAWS act 5683, § 2(7) (Deering 1962).

20 See note 30 infra and accompanying text.

21 Orange County Water Dist. v. City of Riverside, 188 Cal. App. 2d 566, 10 Cal. Rptr. 899 (1961). Plaintiff settled for less than a complete adjudication of rights, since not all pumpers on the stream were made parties, and the safe yield of the system was not determined. Upstream pumpers who were parties were restricted to their unadjusted prescriptive rights, but apparently other pumpers on the stream could continue to acquire new prescriptive rights. The case illustrates that unless the elements of the Raymond Basin solution are present, complete control of the local supply cannot be realized.

22 Organized under the Municipal Water District Act of 1911, CaI. UxcodIfIEd Water Laws act 5243 (Deering 1962).

23 See CaL. WATER CODE $\$ 154$ (abolishing Division of Water Resources) and $\$ 179$ (investing State Water Rights Board with powers and duties of Division of Water Resources, inter alia). 
for determination of physical facts. To name all the interested parties was an enormous task. While the list of defendants was being compiled new pumpers were sinking wells. Resourcefully, the chief parties to the litigation saw the need for an interim order that would temporarily control most of the extractions. Such a decree was finally worked out by a stipulation that inchided an arrangement for the exchange of waters. Further negotiations made possible the entry of a final judgment in that case in 1961, pursuant to a stipulation of the parties. ${ }^{24}$ Here again the limitation imposed on pumpers by the court made the use of Colorado River water necessary. ${ }^{25}$

While actions to save the West Basin have been taken, its problems have been aggravated by the upstream activities within the Central Basin Municipal Water District, where rights have not been adjudicated. The inequity of this situation was well stated by the manager of both the West and Central Basin Municipal Water Districts, when he said:

The West Basin has operated for several years under court approved curtailment of pumping. Only $30 \%$ of the water used in West Basin is supplied by wells, $70 \%$ is furnished by The Metropolitan Water District, and this has helped stabilize water levels. Pumping in Central Basin is unrestricted and $83 \%$ of the water used there is produced from wells, while only $17 \%$ is furnished by Metropolitan.

There are 37 service connections to The Metropolitan Water District system in Central Basin having a total capacity of 530 second feet. They are seldom used because producers are not willing to reduce pumping in an area where no legal action has been taken to adjudicate water rights. They know that under the decision in the Raymond Basin case, the more water a producer pumps, the greater his right becomes, and that if he reduces his pumping, his water riglit could be proportionately impaired. ${ }^{20}$

The leaders of both districts found a partial solution to their inter-basin problems by the organization of the Central and West Basin Water Replenishment District in 1959.27

\section{Legislative Response}

The above situations are indicative of the problems that led the California Legislature to venture cautiously into the field of ground water management in 1955 . Aside from the special act creating the Orange County

24 California Water Serv. Co. v. City of Compton, Civil No. 506806, Super. Court, Los Angeles County, Aug. 22, 1961.

20 West Basin Municipal Water District joined the Metropolitan Water District of Southern California in 1948. See 10tr ANn. Rep. Metropolitan Water Dist. of So. Car. 74-75 (1948).

26 Fossette, Protection and Utilization of Ground Water Basins Through Planned Replenishment and Coordinated Operation, a paper presented to the Governor's Dry Year Water Conference, Los Angeles, California, July 13, 1961.

27 Bookman, Water Supply Problems in the Central Basin, Los Angeles County, California, September 27, 1961. 
Water District, ${ }^{28}$ there was no general law that authorized any public agency to impose a pump tax on pumpers within its boundaries, an essential authority if pumping is to be properly controlled and the costs of importing supplemental water are to be equitably distributed. Municipal water districts already have elaborate powers ${ }^{29}$ and the statute under which they are formed might have been amended to add such a power. However, it was recognized that since most of the member agencies of the Metropolitan Water District were municipal water districts organized for the purpose of buying imported Colorado River water, no thought had been given to conforming their boundaries with the geologic structure of ground water basins. Inasmuch as pumpers were to be taxed to pay for imported water to supplement the basin from which they pumped, it was felt the replenishment district boundaries should conform to the ground water basins involved. Hence the Water Replemshment District Act of 1955 enables interested persons in the seven counties of Southern California to organize a district that can levy ad valorem taxes, impose a pump tax, charge directly for the sale of water, exchange water, adjust costs, replenish the ground water basins, and even initiate actions to adjudicate the rights of pumpers within its boundaries.$^{30}$ Such an entity must acknowledge the adjudicated rights of its pumpers and charge a pump tax only on the excess production over adjudicated rights. ${ }^{31}$ In order to make the replenishment program work in the West and Central Basins, the Central and West Basin Water Replenishment District has instituted an adjudication to bring the pumpers in the Central Basin under the sanie degree of control as the West Basin pumpers. ${ }^{32}$ Like the Raymond Basin interests, these

28 See note 16 supra.

20 See Municipal Water District Act of 1911, Cat. Uncopneted Water LAws act 5243 (Deering 1962).

30 Cax. WATER CODE $\$ \$ 60000-449$.

31 CAL. WATER CODE $\$ 60350$ provides:

In the event of an adjudication of all or substantially all of the rights to extract ground water and a determination of the natural safe yield of the ground water supplies within the district, and a determination of the amount or extent to which the rights to extract ground water so adjudicated may be exercised without exceeding the natural safe yield of such ground water supplies, the board of such district shall recognize such judicial determination by exenpting from the replenishment assessments the amount of water pumped by each person whose rights lave been so adjudicated which does not exceed his proportionate share of the natural safe yield of the ground water supplies of the district, as so adjudicated from time to time by the court having jurisdiction over such adjudication proceeding. The replenishment assessment shall thenceforth he levied on each producer by multiplying the production in acre-feet of ground water so produced by such producer's water-producing facility in excess of his said adjudicated share of the natural safe yield by the rate of the replenishment assessment fixed and levied by the board for the fiscal year in which such production shall occur.

32 See Cax. WATER CODE $\$ 60230(7)$, confirming the power of the district to initiate an adjudication of ground water rights within the district. 
two entities downstream on the same watershed appear to share the conviction that control over the utilization of the local supply through court action is a necessary condition to effective management of ground water basins supplemented by imported water.

The experience in ground water adjudications to date indicate that suits were instituted only after the ground water basins were in real trouble. The proceedings have been lengthy, cumbersome, and expensive. Unless the parties were able to agree on some regulation pending trial, the situation in each water basin worsened. Apparently no attempt was made to 'seek relief by preliminary injunction, even -though such relief has frequently been ordered in stream adjudications. ${ }^{33}$ Yet there is every reason for the courts to use the injunctive tool in ground water adjudications. Sufficient geologic and hydrologic data have been compiled by the United States Geological Survey, the Department of Water Resources, and other agencies for most of the critical ground water areas of the state to enable the courts to evaluate basin conditions for the purpose of considering a preliminary injunction. Several of the stream systems in Southern California have already been found by the courts to be overdrawn, in whole or in part. In still other cases the parties have stipulated to a condition of overdraft. A preliminary injunction is proper where the court on affidavits finds that a prohibitory injunction preventing accelerated exhaustion of the water supply, or a mandatory injunction directing a cutback in extractions, is necessary to prevent irreparable damage to the parties. ${ }^{34}$

This type of temporary injunctive rehef was made more feasible by the adoption of the Water Recordation Act in $1955{ }^{.55}$ Under it all persons in the counties of Los Angeles, Riverside, San Bernardino, and Ventura who extract ground water in excess of twenty-five acre feet annually must file a "Notice of Extraction and Diversion of Water" with the State Water Rights Board. In this manner pumping information that would be of benefit to the courts in considering a preliminary injunction has been compiled. Inasmuch as the facts contained in the notice are not admissible in evidence, at least until the board makes an administrative determination on request, the usefulness of the machinery is somewhat impaired. ${ }^{36}$ While it may be argued that this evidentiary restriction was not intended to limit

33 E.g., Fresno Canal \& Irrigation Co. v. People's Ditch Co., 174 Cal. 441, 163 Pac. 497 (1917) ; Miller \& Lux v. Madera Canal \& Irrigation Co., 155 Cal. 59, 99 Pac. 502 (1909); Porters Bar Dredging Co. v. Beaudry, 15 Cal. App. 751, 115 Pac. 951 (1911).

34 See Car. Code Crv. Proc. $\$ \S 526,527,530$.

35 CAT. WATER CODE $\$ \S 4999-5008$. The same information is collected and made available as a public record under the Orange County Water District Act, CAI. UNCODIFIED Water LAws act 5683, $\$ \S 29-31$ (Deering 1962).

36 See CaI. Water Code $§ 5007$. 
the use of the data as an admission against the interest of the declarant, but only intended to prohibit the court from considering the data as a selfserving declaration against others, the legislature should clarify the language and make the data admissible in any proceeding. Furthermore, the act should be extended to cover the entire state, exempting only those areas that already carry on a mandatory system of pumping recordations that are public records. ${ }^{37}$

The legislature's interest in ground water management was carried even further in 1961. An interim committee of the Assembly was directed to study the legal, physical, economic, and managerial problems of fully utilizing the ground water basins of California. ${ }^{38}$ The Assembly Interim Committee on Water is currently conducting hearings in all parts of the state pursuant to that directive.

In 1961 the legislature adopted the Porter-Dolwig Ground Water Basin Protection Law. ${ }^{30}$ This act declares that the people of the state have a primary interest in preventing irreparable damage to, and correcting impaired use of, the ground water basins of the state caused by critical conditions of overdraft, depletion, sea water intrusion, or degraded water quality. The Department of Water Resources is directed to "initiate investigations, studies, plans and design criteria" for the construction of projects that the department considers to be practical, economically feasible, and urgently needed for the protection of ground water basins. ${ }^{40}$ The department is authorized to review, evaluate, and revise the plans and design criteria for any project for such purposes submitted to it by a local agency. An appropriation of 250,000 dollars to the Department of Water Resources was included. The act amplifies and extends the studies by the department that had been initiated previously to develop management plans for the ground water basins in Southern California.

The legislature also considered a bill during the 1961 session to authorize the State Water Rights Board, on petition of persons who have recorded takings of ten per cent or more of all recorded water in any specific ground water basin, to institute an adjudication for any distressed ground water basin. ${ }^{41}$ The bill would authorize the court to issue a preliminary injunction without bond, restricting pumpers to amounts that would not irreparably injure or destroy the basin. The proposed legislation is far-reaching, in that it invites state participation in local ground water problems with extensive powers not now enjoyed by local political subdivisions. The bill

\footnotetext{
37 See note 35 supra.

38 A. Res. 179, Cal. Leg., Reg. (Gen.) Sess. (1961).

30 CaI. Water Code $\S \S 12920-25$.

40 CaL. Water CODE $\$ 12923$.

41 A.B. 3042, Cal. Leg., Reg. (Gen.) Sess. (1961).
} 
has been referred to as a proposal for "simplified adjudication." "42 An analysis of the bill reveals not so much simplification, as the vesting of more judicial power in state agencies. Not only would the new powers be extensive, but they would be exercisable only by the state.

The response to this proposed legislation has not been altogether sympathetic. In view of the ad hoc solutions that many of the ground water areas in Southern California have already achieved, plus a natural reluctance to invite state interference in local affairs, many agencies have gone on record as opposing such drastic legislation. On the other hand, it must be pointed out that legislation of this type will continue to be pressed so long as local agencies do not vigorously pursue solutions to their own ground water problems. It is axiomatic that larger units of government will interfere in purely local problems if responsible officials of the local units fail to recognize critical problems and do something about them.

A quasi-judicial solution to some of the problems has been recommended by the Chairman of the State Water Rights Board. ${ }^{43}$ Finding the present statutes and administrative practices of the board satisfactory for surface stream adjudications, he proposes that the existing statutory procedure be extended to the adjudication of ground water sources. He also proposes that the present Water Recordation Act be extended statewide; that the present system of applications, permits, and licenses that applies to surface streams be extended to include ground water; and that a statewide procedure be worked out by which ground water areas may be administratively defined. Pending a thorough review and clarification of the whole field of water rights administration by the state, it would appear more prudent to continue to use the offices of the State Water Rights Board as a fact-finding body rather than in the capacity of a quasi-judicial board, insofar as ground water is concerned.

Thus far we have been discussing regulation of the use of ground waters in an overdrawn stream system. We have reviewed the methods used by various public agencies in solving the problems of their own areas. The judicial tools have been reviewed and some of the problems in connection with their use have been analyzed. The legislature's interest in the problem has been touched on. In summarizing our conclusions concerning basin control and regulation, the following may be stated:

1. Each area overlying a ground water basin has two problems. The first is to balance the supply and demand within its own boundaries. The second is to assure itself its just proportion of the waters of an overdrawn stream system.

42 Goodcell, Ground Water Basin Management, a paper presented to the Annual Conference of the American Water Works Ass'n, Sacramento, California, Oct. 26, 1961.

43 Statement by Kent Silverthorne, Chairman of the State Water Rights Board, before the Assembly Interim Committee on Water, Sacramento, California, Aug. 29, 1961. 
2. Any basin may solve its own internal water supply problem either by (a) adjudication of the local supply and enforced purchase of supplemental water by water users; or (b) supplementation of the local supply by direct purchases of supplemental water without adjudication. This imported supply may then be substituted for pumped water by those purchasers who agree to buy it, or the imported water may be spread by a political subdivision to supplement the local basin supply. In this latter event there is an intricate balancing of political powers involved, including charges for supplemental water, pump taxes, and ad valorein taxes. In addition, a high degree of cooperation among the mumicipal, industrial, and agricultural users is required. Furthermore, it is unlikely that self-regulation without adjudication would be permanently satisfactory in any areas save the last one on the streain system, because downstream users cannot depend on upstream users using only their fair share of the local supply.

3. Facing the streain problem, it would appear that each basin has an interest in adjudicating the rights of users in basins upstreain from it, but not the interests of those downstream. Each basin's full share of the stream's supply depends upon adjudicating upstream rights and policing all future uses. Only the courts are able to regulate and control the quantities of water upstream users are entitled to take. Not only must there be a judicial determination of those rights, but the enforcement of the decree is a matter of continuing judicial responsibility. The remedies afforded by the law in the way of physical solutions and penalties for contempt are the necessary tools for implementing stream systein control.

The use of underground storage for imported water cannot be completely successful unless the natural local water supply has been fully adjudicated so that extractions can be controlled and the basin fully managed.

\section{III}

\section{UNDERGROUND STORAGE}

It has long been a policy of the Metropolitan Water District of Southern California to demand that local agencies provide their own storage. It is a demand that has been honored more in the breacli than in the observance. In the first place, there has been little need to enforce the rule, because the capacity of Metropolitan's lines and surface storage facilities has so far enabled users to meet their demands directly from its main distribution lines. However, the problein becomes more pressing as Metropolitan approaches delivery of the full flow of the Colorado River Aqueduct, ${ }^{44}$ and

44 The Metropolitan Water District of Southern California delivered 935,227.1 acre feet of water in 1960-61. See 23rd ANn. Rep. Metropolitan Water Dist. of So. CaL. 5 (1961). Arizona las challenged the District's claim to $1,212,000$ acre feet annually from the Colorado River, Arizona v. California, oral argument, 30 U.S.L. Week 3238 (U.S. Jan. 30, 1962). 
preparations are made to deliver $1,800,000$ acre feet of water from Northern California.

The state has only limited terminal storage facilities for the water it is importing. More storage will be needed either by the state or by the parties with whom it is contracting to deliver water. Additional surface storage, if available at all, would be extremely expensive. Ground water storage would not only be less expensive, but more desirable in many respects, such as low evaporation losses. The full extent of this storage demand is readily apparent when one considers that storage is necessary not only for the daily and monthly variations in demand, but for seasonal fluctuations and cyclical variations. If supplemental water is to be made available to Southern California in 1972 as the state now intends, certainly the problem of terminal storage should be resolved long before that time. It is this challenge that requires us to consider the use of underground capacity for storing imported water.

It has been estimated that California has a potential underground storage capacity of $450,000,000$ acre feet. ${ }^{45}$ Southern California has an estimated underground storage capacity equal to $8,781,000$ acre feet, against total ground water storage requirements of $7,650,000$ acre feet by the year $1990 .^{46}$ The problem then is how to put this invaluable resource to work.

Several things are needed to store imported water underground: spreading works, a storage basin with capacity available for the new water, and a means of recapturing the stored water. Of these three requirements, the storage basin is the most important. It is our conclusion that the underground may be used for storing imported water, and without having to compensate overlying owners in the absence of actual damage.

The leading case on the use of ground water basins for storage is City of Los Angeles v. City of Glendale. ${ }^{47}$ Los Angeles sought a declaration of its rights to waters of the Los Angeles River, most of which arose from the water-bearing strata of the San Fernando Valley. In addition to the local sources, the San Fernando basin was fed by water imported by Los Angeles from the Owens River Valley and either spread or sold to San Fernando Valley farmers. As anticipated, a portion of the water sold sank beneath the surface, to be reclaimed at the lower end of the valley. The cities of Glendale and Burbank, which were pumping from the basin, were named as defendants. The Supreme Court of California held that:

Plaintiff had a prior right to the use of the water brought to the San Fer-

45 State of Calif., State Water Resources Board, Dep't of Water Resources, Buly. No. 3, The Californla Water Plan 13 (1957). There are some 250 ground water basins in California. The storage capacity was estimated on an average weighted interval of approximately 185 feet, or generally between depths of about 15 and 200 feet below the surface.

46 Morris, Need for Water Storage-Surface and Underground, a paper presented to the Feather River Project Ass'n, Los Angeles, California, Oct. 12, 1961.

4723 Cal. 2d 68, 142 P.2d 289 (1943). 
nando Valley. It did not abandon that right when it spread the water for the purpose of economical transportation and storage. . . It would be as harsh to compel plaintiff to build reservoirs when natural ones were available as to compel the construction of an artificial ditch beside a stream bed. ... [I]n selling water to the farmers, as in spreading water, plaintiff was interested in its economical transportation and storage. . . Once within the basin . . it was in effect within plaintiff's reservoir. ${ }^{48}$

Since there had been no actionable invasion of the plaintiff's rights by defendants, there was no possibility of a prescriptive right maturing in their favor. ${ }^{40}$

A significant feature of the opinion is its reliance on the predecessor of Water Code section 7075. ${ }^{50}$ That section, which provides for the use of stream channels to transport appropriated water, was broadly construed to authorize an entire spreading and reclamation operation. Under it, no authority from the state is required, and none was recognized. Nor were the activities of the city in importing, spreading, and subsequently recapturing the foreign water ever challenged.

In apparent reliance on the same section, other public agencies have carried on spreading activities without permission from the state. For example, the Los Angeles County Flood Control District has for many years engaged in an extensive and beneficial conservation program. Storm waters, imported Colorado River water, and more recently treated sewage effluent have been spread. ${ }^{51}$ The Central and West Basin Water Replenishment District is currently engaged in cooperative efforts to spread Colorado River water, as well as treated sewage effluent, ${ }^{52}$ and the Orange County Water District has spread more Colorado River water than any other member agency of the Metropolitan Water District of Southern California. ${ }^{\tilde{3}}$ Unlike the program of the City of Los Angeles, the water spread by these agencies is for the benefit of all of the pumpers in the respective areas. It is not recaptured by the spreading agency.

A third method of spreading appropriated water is to seek permission to store the appropriated water for future use. This is specifically authorized by section 1242 of the Water Code. Under it the City of Sierra Madre sought and obtained authority from the predecessor of the State Water Rights Board to divert stream flow by pipeline to spreading works, and

48 Id. at $76-78,142$ P.2d at 294-95.

40 Id. at 79-80, 142 P.2d at 295-96.

$50 I d$. at 78,142 P.2d at 295.

51 Hearings on Ground Water Problems before the Assembly Interim Committee on Water, Anaheim, California, Nov. 29, 1961, at 66-97, testimony of Finley B. Laverty, Assistant Chief Engineer, Los Angeles Flood Control District, on Water Conservation in Los Angeles County. 52 Bookman, Control and Reduction of Ground Water Pumping in the Central Basin, Los Angeles County, California, a report dated Oct. 10, 1961, prepared for the Central Basin Water Ass'n; see Assembly Hearings supra note 51, at 126.

53 Crooke \& Toups, op. cit. supra note 17. 
was granted permission to pump the stored water within limits carefully defined by the board. ${ }^{54}$

A novel situation arises when several agencies seek to store imported water in the same underground reservoir. With underground storage capacity at a premium, this condition is likely to arise soon. In the absence of clarifying legislation the courts could handle the problem in several ways. First, they could treat storage capacity like surplus water and apply the doctrine of "first in time, first in right" to the several agencies actually storing water underground. Or the courts might read section 1242 of the Water Code as conferring on the State Water Rights Board the authority to grant permission to store water underground. In this event the board could, under its broad discretionary powers, permit storage to several applicants, specifying the terms and conditions of cooperation and joint use that would best advance the public interest. ${ }^{55}$ Also, the courts might reason that individual agencies purchasing water from the state enjoy a derivative right to store water underground for future use under section 1242 of the Water Code. If this be so, the state might consider amending its applications with the State Water Rights Board so as to specifically request authority on the state's behalf, or for the benefit of any parties contracting with the state for appropriated water, to store water in the underground basins of the state for future use. In view of the considerable importance attached to multiple demands on underground storage capacity, the legislature might well consider the enactment of more specific legislation authorizing the use of this natural resource by multiple applicants. A guide to the method of handling a joint use of facilities is afforded in those provisions of the Water Code dealing with the joint use of wells, pumping plants, and conduits. ${ }^{\text {to }}$

Storage of appropriated water in the underground for future use still leaves open the question of liability to the overlying owner. If the old common-law inaxim cujus est solum ejus est usque ad coelum et ad inferos were to be strictly applied, the agency storing water underground might incur hability because of the subsurface invasions of another's wedge of the earth. However, despite California's adoption of the rule, ${ }^{57}$ the courts have not hesitated to modify it when necessary to ineet the needs of a time

54 On December 31, 1948, Application No. 12888 was filed by the City of Sierra Madre with the Division of Water Resources seeking authority to divert water from the Santa Anita Canyon to spreading grounds owned by the city, and for authority to store the water underground for future recapture. The application was granted by Permit 7468, issued by the Division of Water Resources August 9, 1949, specifically approving the purposes set forth in the application, and limiting the amount of water that could be extracted from the spreading grounds to 1500 acre feet. A second application and permit increased this amount to 5000 acre feet annually.

65 See Cax. Water Code $\$ \S 1253,1256$.

56 Cax. Water Code $\$ \S 7000-10$.

57 Cax. CIv. Code $\$ 829$. 
and place very cufferent from that in which it was born. ${ }^{58}$ Cases refusing to enjoin unconsented invasions of airspace above privately owned land are persuasive analogues. ${ }^{59}$ Their reasoning is equally applicable to the use of ground water storage capacity. ${ }^{60}$

Of course, a spreading agency might invade the property interests of the overlying owners in several ways. If too much water is stored in the underground the ground water level might rise and flood either structures or crops, in which case the injured party would be entitled to full compensation. If the water level is arbitrarily drawn down for management purposes, the pumper who has to lower his well and pump from a greater depth should likewise be compensated.

The complete operation of a spreading program requires spreading works as well as facilities to recapture the stored water. Ordimarily, the best means of spreading water into the underground is through the use of stream channels. As already noted, the use of these channels for that purpose is expressly permitted by statute and case law. ${ }^{61}$ In many instances, especially where there has been heavy urbanization, the natural stream channels have been cemented in order to accelerate the disposition of flood waters to prevent damage. It has therefore been necessary to rely on offstream spreading works. Frequently these sites must be acquired by negotiation or condemnation. Almost all public agencies concerned with spreading water enjoy the power of eminent domam. These same agencies also have specific power to cooperate with other governmental agencies in matters of common concern, and cooperative efforts are enhanced by the Joint Exercise of Powers provisions of the Government Code. ${ }^{62}$ Where a conflict arises over the use of spreading grounds, the statutory provisions governing condemnation are quite flexible. The state and certain political subdivisions, including municipal water distrcts, may condemn property already appropriated for public use, if the new use is consistent with the existing use, and the court may fix the terms and conditions upon which such property nuay be taken. ${ }^{63}$ However, the same property may not be

58 See Katz v. Walkinshaw, $141 \mathrm{Cal} .138,70$ Pac. 663 (1902), rehearing, $141 \mathrm{Cal} .116$, 74 Pac. 766 (1903); Orange County Water Dist. v. City of Riverside, 188 Cal. App. 2d 566, 10 Cal. Rptr. 899 (1961) ; Hutchins, THE CaLIForNIA Law of Water Rights 432-35 (1956).

${ }^{60}$ See United States v. Causby, 328 U.S. 256 (1945); Hinman v. Pacific Air Transp., 84 F.2d 755 (9th Cir. 1936).

60 United States v. Causby, supra note 59, at 261: "To recognize such private claims to the airspace would clog these highways, seriously interfere with their control and development in the public interest, and transfer into private ownership that to which only the public has a just claim."

61 Cat. Water Code $\$ 7075$; City of Los Angeles v. City of Glendale, 23 Cal. $2 d 68$, 142 P.2d 289 (1943).

62 CaL. Gov'T Code $\$ \S 6500-78$.

${ }^{63}$ CaI. Code Crv. Proc. § 1241(3). 
taken from the entities on whom this special power to take is conferred. The legislature might well consider a modification of the law of eminent domain that would permit the state, or any agency contracting with it for water appropriated by the state, to condemn wholly or in part the necessary works for spreading such water for storage in the underground for future use. Such authority appears consistent with the broad powers conferred on the state to safeguard its entire water supply and to put it to its maximum beneficial use. ${ }^{64}$

As in the case of spreading grounds, most agencies concerned with the several phases of ground water management enjoy the power to acquire by eminent domain the properties necessary to recapture water. This includes well sites, pumping and storing facilities, easements, and necessary appurtenances. In addition, any management agency could probably contract to use production and transmission facilities already in existence but owned by others. The only problem is to make full and efficient use of all the facilities already available for the recapture, transmission, and distribution of the imported water that has been stored underground.

\section{IV}

\section{ORGANIZATION}

Management of ground water basins on a stream system poses a major challenge to the political scientists. The complex of existing political units, each dealing with a part of the problem, must not only be coordinated, but new responsibilities created by new circumstances must be woven into the political fabric. Such interweaving must be accomplished with continuous attention to both the vertical and horizontal integration of existing agencies. Vertical integration is necessary because there are several layers of political authority overlapping the affected areas. For example, inside the Metropolitan Water District of Southern California, which embraces almost 4,000 square miles of territory, with an assessed valuation of $14,000,000,000$ dollars and a population of $7,600,000$, there are eleven municipal water districts, one county water authority and ninety-three incorporated cities, of which thirteen are corporate member agencies of the master district. ${ }^{65}$ That district's chief responsibility is to import supplemental water into Southern California for the benefit of its member agencies. In turn the member agencies build the necessary works to make that water available to water distributing entities, public and private, within their local boundaries. Overlying this structure are flood control, sanitation, sewer, conservation, and community services districts, and a multitude of other agencies. Their activities all impinge in some manner on

64 Cax. Const. art 14, \& 3 ; Cax. Water Code $\$ 100$.

65 23rd Ann. Rep. Metropolitan Water Dist, of So. Cax. 1 (1961). 
water supply and disposal. Standing over all are important state agencies such as the Department of Public Health; the State Water Pollution Control Board, and its regional boards; the Department of Water Resources; and the State Water Rights Board, with its extensive jurisdiction over surplus waters, water records, supervision of dams, and investigation and watermaster activities. At the federal level is the Bureau of Reclamation and the Army Corps of Engineers, as well as programs to aid local water projects by the loan of federal funds.

Horizontally, the problem is one of integrating agencies that have substantially the same powers, but that have control over only part of the stream system. Frequently agency boundaries are contiguous, but their interests are divergent. Each is seeking a lion's share of the local water supply, because imported water is more expensive. It is at this level, in particular, that physical solutions challenge the resourcefulness of the legislature. The problem may be reached in several ways: (1) extend the powers of existing agencies; (2) enlarge the area of cooperation through the Joint Powers Act; and (3) superimpose a new agency with limited powers over those already existing.

The extension of powers of existing agencies to attain full basin management raises several problems. Most existing agencies were created either by vote of the people within them or by the legislature for specific purposes, such as water supply, reclamation, or flood control. To enlarge those powers by legislative fiat would not only confer powers not originally contemplated by the electorate, but in some cases would create a conflict with other agencies with similar powers already occupying the field. On the other hand, any amendment to the Joint Powers Act ${ }^{66}$ that will make cooperation between agencies more attractive is to be encouraged. However, the use of that act, as well as the free use of the power to join with other federal, state, and local agencies in carrying out any of the agency's functions, is permissive only. ${ }^{67}$ Without a requirement that action be taken, such authority is a doubtful solution to the management problem. It would appear, then, that a new agency with carefully drafted powers is the most desirable method of achieving ground water basin management.

The nucleus of such an agency is found in the Water Replenishment District Act. ${ }^{68}$ The act provides for the establishment of boundaries, with the approval of the Department of Water Resources, to include persons or property directly or indirectly benefited by the program; ${ }^{69}$ the recog-

${ }^{6 B}$ CAL. GOv'T CODE $\$ \S 6500-78$.

67 E.g., Municipal Water District Act of 1911, Cax. Uncodified Water Laws act 5243, $\S 12$ (14) (Deering 1962).

68 CaL. Water Cone $\S \S 60000-449$.

${ }^{69}$ CaL. Water Code $\S 60101$. 
nition of existing agencies with substantially the same powers; $;^{70}$ exempting areas already under a replenishment authority with power to levy a pump $\operatorname{tax} ;^{71}$ the power to buy, sell, and exchange water and to distribute water in exchange for reducing ground water extractions; ${ }^{72}$ initiating the adjudication of water rights within or without the district; ${ }^{73}$ levying assessments on pumping within the district ${ }^{74}$ the recognition of any judicial determination of water rights by exempting them from replenishment assessments; ${ }^{75}$ and the power and duty to contract with existing agencies for the use of their facilities to accomplish the purposes of the district, if it is found to be "more economical and for the best interests of the area to be benefited."70

The last provision enumerated is believed to be the first of its kind in California. Under it the taxpayers, as well as existing agencies, are afforded protection against duplicated expenditures by new agencies having parallel powers.

To be fully effective the Water Replenishment District Act might well be amended to include additional powers. The act already respects the identity of existing agencies, prohibits the inclusion of areas already under a replenishment program, and even compels the use of the facilities of existing agencies to accomplish its purpose. It would appear prudent to include powers to acquire a water supply and to construct or own the facilities necessary to make an entire management program feasible. The powers contained in the Municipal Water District Act of $1911,{ }^{77}$ the County Water District Law, ${ }^{78}$ and the new powers added to the Alameda County Water District in $1961^{79}$ might well be used as a guide in this direction. Effective management would also be enhanced by vesting the board of directors of the district with the power, after public hearing, to create zones of benefit within its boundaries. This mechanism has recently been incorporated in a special act known as the Kern County Water Agency, created by the legislature in $1961 .^{80}$ The flexibility afforded by this provision would permit the governing body to recognize that some areas within its boundaries will receive greater benefits than others in the execution of a full management program involving the spreading of water and subsequent recapture at various levels. Finally, the act should be extended to cover the entire state.

70 CAL. WATER CODE $\$ 60041$.

71 CAL. WATER CODE $\$ 60045$.

72 Cal. Water COde $\$ 60221$.

73 CAL. WATER Code $\$ 60230(7)$.

74 Cac. Water CODE $\$ 60317$.

75 CAL. Water CODE $\$ 60350$.

76 CAL. WATER CODE $\$ 60231$.

77 See note 67 supra.

78 CAI. WATER CODE $\$ \S 30000-3901$.

79 Cal. Stats. 1961 ch. 1942.

80 CAL. UNCODIFIED WATER LAws act 9098, $\$ 14.2$ (Deering 1962). 
CONCLUSION

Ground water basin management in the urbanized and water-short areas of California demands the immediate attention of our courts, lawmakers, local goverming bodies, and water distributing entities. The skill and resources of lawyers, engineers, geologists, economists, financiers, and political scientists must be brought to bear on the multitude of complex problems created by the shortage. All water rights in critical ground water basins should be brought under the immediate and continuing jurisdiction of the courts. Water imported from outside the watershed must be stored underground with local waters, and the commingled supply maintained at levels commensurate with the maximum utilization of the basins for all purposes. To achieve this, existing agencies must exercise their joint powers liberally and constructively with a view to stream-wide conservation. Where a new authority is required to achieve interbasin management, the Water Replenishment District Act is the most promising vehicle available. Resourceful and farsighted amendments are needed to clarify areas in which the law is uncertain and to equip governing bodies with the necessary powers to effectuate overall ground water basin management. 